may well be fortuitous or related to the increasing use of this procedure, or may be related to the initial reason for advising sterilization. All three of our patients had psychological reasons for seeking sterilization and, in addition, one had already established hypertension on the basis of chronic pyelonephritis. The possibility exists that the relation between the use of oral contraceptives and the disease could be due to the contraception itself rather than to its methods of achievement. This might be worth looking into before concluding that oral contraceptives are a risk factor in acute myocardial infarction and before recommending sterilization as a preferable method of contraception.

It is now well established that the risks of developing ischaemic heart disease prematurely are increased in association with excess cigarette smoking (Doll and Hill, 1964), hypercholesterolaemia and hypertension (Truett et al., 1967), abnormal carbohydrate tolerance (Epstein, 1967), a family history of the disease (Thomas and Cohen, 1955), a premature menopause (Sznajderman and Oliver, 1963), and perhaps also obesity (Truett et al., 1967). Every patient in the present series had at least one of these predisposing risk factors for coronary artery disease and the average score for risk factors was $2 \cdot 6$.

Few women in the present series were non-smokers. Some of those not allocated a point score for smoking were, in fact, smokers, though of fewer than 20 cigarettes a day. Kay et al. (1969) observed that women using oral contraceptives were heavier smokers than non-users. Oliver (1973) found that $47 \%$ of women with documented ischaemic heart disease under the age of 45 years were smokers. This compares with $26 \%$ of women in the same age group in the general population of the United Kingdom (Todd, 1972). It is established that oral contraceptives can raise the concentration of serum cholesterol and triglycerides (Wynn et al., 1969). Also there is an association between oral contraceptive therapy and the onset and aggravation of hypertension (Laragh et al., 1967; Woods, 1967; Weir et al., 1971). Obviously all these factors are interrelated and must be taken into account in interpreting the role of oral contraceptives in myocardial infarction.
The available evidence suggests that it would be wise to identify those risk factors commonly associated with ischaemic heart disease in young women about to start oral contraceptive therapy. It is easy to screen for hypertension and to monitor blood pressure subsequently. In those with a family history of precocious ischaemic heart disease a case can be made for screening for abnormalities in blood lipid concentrations and also for giving advice against cigarette smoking. In those with identifiable risk factors alternative contraceptive measures should be advised or, if personal circumstances demand, the duration of oral contraceptive use should be limited.

\section{References}

Boyce, J., Fawcett, J. W., and Noall, E."W. P. (1963). Lancet, 1, 111. Dear, H. D., and Jones, W. B. (1971). Annals of Internal Medicine, 74, 236. Doll, R., and Hill, A. B. (1964). British Medical fournal, 1, 1399.

Epstein, F. H. (1967). Circulation, 36, 309.

Fischer, A., and Mosbech, J. (1970). Ugeskrift for Lager, 132, 2480

Harveit, F. (1965). British Medical fournal, 1, 60.

Inman, W. H. W., and Vessey, M. P. (1968). British Medical fournal, 2, 193. Kay, C. R., Smith, A., and Richards, B. (1969). Lancet, 2, 1228.

Laragh, J.. H., Sealey, J. E., Ledingham, J. G. G., and Newton, M. A. (1967). Fournal of the American Medical Association, 201, 918.

Naysmith, J. H. (1965). British Medical fournal, 1, 250.

Oliver, M. F. (1970). British Medical fournal, 2, 210.

Oliver, M. F. (1973). American fournal of Cardiology. In press.

Oliver, M. F., and Boyd, G. S. (1959). Lancet, $2,690$.

Robinson, R. W., Higano, N., and Cohen, W. D. (1959). Archives of Internal Medicine, 104, 908 .

Rose, G. A., and Blackburn, H. (1968). World Health Organization. Monograph Series. No. 56.

Scharf, J., Nahir, A. M., Peled, B., and Asad, A. (1968). Lancet, 2, 411.

Sznajderman, M., and OOliver, M. F. (1963). Lancet, 1, 962.

Thomas, C. B., and Cohen, B. H. (1955). Annals of Internal Medicine, 42, 90. odd, G. F. (1972). Statistics of Smoking in the United Kingdom. London, Tobacco Research Council.

Truett, J., Cornfield, J., and Kannel, W. (1967). Fournal of Chronic Diseases,

Waxler, E. B., Kimbiris, D., Van Den Brock, H., Segal, B. L., and Likoff, W. (1971). American Yournal of Cardiology, 28, 96.

Weir, R. J., et al. (1971). Lancet, 1, 467.

Weiss, S. (1972). New England fournal of Medicine, 286, 436.

Woods, J. W. (1967). Lancet, 2, 653.

Wuest, J. H., Dry, T. J., and Edwards, J. E. (1953). Circulation, 7, 801

Wynn, V., Doar, J. W. H., Mills, G. L., and Stokes, T. (1969). Lancet, 2, 756.

\title{
Preliminary Evaluation of "Duodenitis" by Endoscopy and Biopsy
}

\author{
P. B. COTTON, A. B. PRICE, J. R. TIGHE, J. S. M. BEALES
}

British Medical fournal, 1973, 3, 430-433

\section{Summary}

Difficulty in excluding duodenal ulceration by standard radiology has hampered investigation of duodenitis; endoscopy and biopsy add a new dimension. We have studied 51 patients with dyspeptic symptoms or bleeding in whom endoscopy revealed congested and irregular areas of duodenal bulb mucosa in the absence of ulcer or scar. Biopsy revealed unequivocal active inflammationepithelial cell atypia and neutrophil infiltration-in 22 of these patients, but in none of 29 "control" patients with

St. Thomas's Hospital, London SE1 7EH

P. B. COTTON, M.D., M.R.C.P., Senior Medical Registrar

A. B. PRICE, B.M., M.R.C.PATH., Senior Registrar in Pathology

J. R. TIGHE, M.D., F.R.C.P., Consultant in Surgical Pathology

J. S. M. BEALES, M.R.C.P.; F.F.R., Consultant in Radiology an endoscopically normal bulb. There were no reliable radiological markers of active duodenitis. These patients, and a group of 25 with known duodenal ulcers, shared similar clinical characteristics and a high incidence of gastric metaplasia in the bulb. In the short follow-up period most patients with active duodenitis remained symptomatic; two developed ulcers, and two others have undergone vagotomy and pyloroplasty, with poor shortterm results. The clinical significance of visual and histological mucosal changes, and their relationship with ulcer disease, merit long-term study.

\section{Introduction}

The existence of a clinically significant duodenal inflammatory condition in the absence of ulceration-"duodenitis"-remains controversial despite an extensive literature dating back as far as 1837 (Baudin). Some early studies were firmly based on examination of the resected duodenal bulb (MacCarty, 1924; Judd and Nagel, 1927; Kirklin, 1929; Rivers 1931), but more 
recently the approach has been largely radiological (Ostrow and Resnick, 1959; Beck et al., 1965; Rhodes et al., 1968; Schulman, 1970).

Patients have been reported on with typical dyspepsia, hyperacidity, and duodenal inflammation (on capsule biopsy) in whom standard barium-meal examinations showed a normal duodenal bulb or enlarged mucosal folds. Studies based on these criteria are difficult to interpret since many of these patients had $x$-ray negative duodenal ulceration (Rhodes et al., 1968).

New fibreoptic endoscopes allow a complete visual and biopsy survey of the oesophagus, stomach, and duodenal bulb (Cotton and Williams, 1972). During over 1,000 fibreendoscopic examinations in the past year many patients with bariumnegative dyspepsia have been shown to have duodenal ulcers (Cotton, 1973). We have also encountered 51 patients whose duodenal bulb mucosa appeared abnormally congested, oedematous, or irregular in the absence of ulcer or scar. The significance of these macroscopic changes has been investigated by multiple endoscopic biopsies; histological, clinical, and radiological data have been compared with those from two other groups of patients in whom endoscopy has shown either a duodenal ulcer or no abnormality.

\section{Patients and Methods}

A total of 104 patients were included in the study. All had abdominal symptoms or anaemia at the time of initial endoscopic examination, which was performed with modern forwardviewing instruments (Olympus GIFD and ACMI 7089P). In $16 \%$ of patients the duodenal bulb survey was judged incomplete, and a lateral viewing duodenoscope (Olympus JFB) was used in addition. Care was taken not to produce mucosal artefacts by instrument trauma. All patients received premedication with atropine $(0.6 \mathrm{mg})$ and diazepam $(5-20 \mathrm{mg})$.

Three groups of patients were studied (table I). Twentyeight patients with normal endoscopic findings were chosen as "controls" (group 1) since their initial symptoms (anaemia or pain) which led to endoscopy were subsequently attributed to
TABLB I-Patients Grouped on Basis of Endoscopic Findings of Duodenal Bulb. Group $3 a$ Consists of Patients from within Group 3 who showed Histologically Active Duodenitis

\begin{tabular}{|c|c|c|c|c|}
\hline Group & Endoscopic Findings & $\begin{array}{l}\text { No. in } \\
\text { Group }\end{array}$ & $\underset{\text { (Range) }}{\text { Mean Age in Years }}$ & Male: Female \\
\hline $\begin{array}{l}1 \\
2 \\
3 \\
3 a\end{array}$ & $\begin{array}{l}\text { Normal } \\
\text { Duodenal ulcer } \\
\text { Visually abnormal } \\
\text { (no ulcer) } \\
\text { Histologically active } \\
\text { duodenitis }\end{array}$ & $\begin{array}{l}28 \\
25 \\
51 \\
22\end{array}$ & $\begin{array}{l}42(19-65) \\
45(19-73) \\
41(12-76) \\
43(15-64)\end{array}$ & $\begin{array}{l}17: 11 \\
21: 4 \\
41: 10 \\
18: 4\end{array}$ \\
\hline
\end{tabular}

disease elsewhere. Twenty-five patients (group 2) had endoscopically proved duodenal ulcers, which were multifocal in four. Group 3 consisted of the 51 patients with no ulcer, but a duodenal bulb mucosa which was macroscopically abnormal. In five patients the mucosa of the entire bulb was congested, oedematous, and roughened; the remainder showed from one to three such areas, rarely more than $5 \mathrm{~mm}$ in diameter, which occurred with equal frequency in all quadrants. Patients with bulb deformity or mucosal erosion were excluded from the study since these changes represent superficial or healed ulceration.

A total of 283 endoscopic mucosal biopsy specimens were taken from normal and abnormal appearing areas of the bulb. Biopsy fragments (2-4 $\mathrm{mm}$ diameter) were shaken off the forceps into $10 \%$ neutral formalin, orientated on card, and fixed. Step-serial paraffin sections were strained with haematoxylin and eosin, periodic-acid Schiff, and a modified Gomori technique for reticulin.

Histological sections (see fig.) were examined by two observers without knowledge of clinical and endoscopic findings. Specimens were rarely large enough for sufficiently accurate orientation to comment on villus shape. Epithelial cell atypia and the presence of neutrophils migrating through epithelia, when present together, were interpreted as unequivocal evidence of inflammation, and constitute histologically "active duodenitis." A subjective assessment was made of the degree of lymphocyte and plasma cell infiltration of the lamina propria; markedly increased infiltration was interpreted as "chronic inflammation."
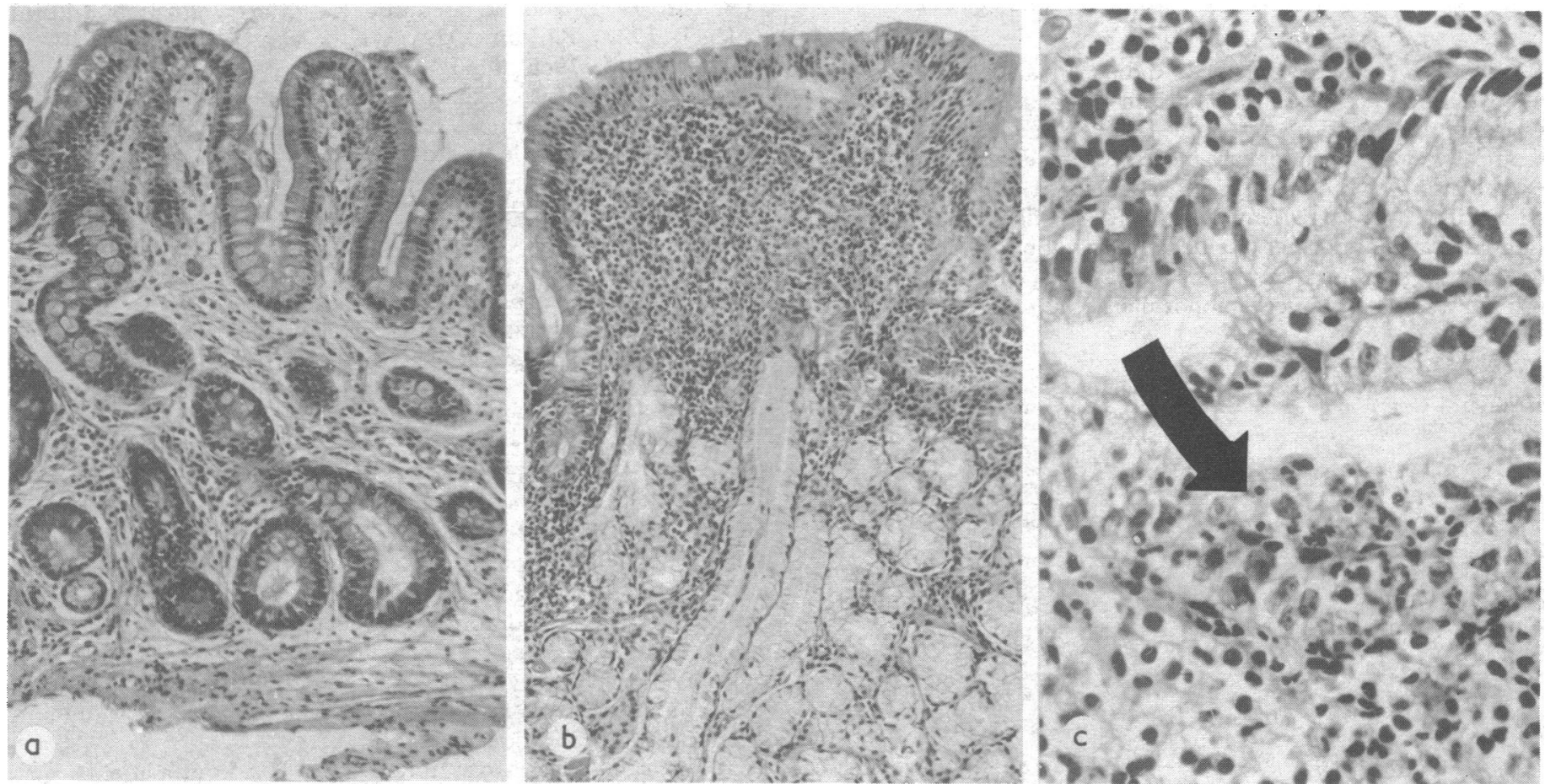

Histological sections of duodenal bulb biopsy specimens: $a$. Normal mucosa. $b$. Chronic inflammation; excessive infiltration of lamina propria by lymphocytes and plasma cells. $c$. Active duodenitis; nuclear atypia of glandular epithelium and infiltration by neutrophils (arrowed). 
Sections were also examined for eosinophilia and for gastrictype mucosal cells (gastric metaplasia).

Barium-meal radiographs were reviewed with particular reference to the appearance of the duodenal bulb, in ignorance of the clinical or endoscopic findings. Clinical follow-up has been brief (6-24 months).

\section{Results}

Histological Changes.-None of the patients with endoscopically normal duodenal bulbs (group 1) showed histological evidence of active duodenitis, in contrast to $22(44 \%)$ of the patients with endoscopically abnormal bulbs (group 3) (table II). However, it must be reiterated that in group 3 mucosal congestion was not uniform and some areas appeared normal. Within this group two biopsy specimens from macroscopically normal mucosa showed histological evidence of active duodenitis. All patients with active duodenitis also showed mucosal chronic inflammation. Chronic inflammatory changes were less specific, however, being present in $25 \%$ of "controls" (group 1) as well as in $58 \%$ of patients with visually abnormal bulbs (group 3 ). Gastric metaplasia was notably commoner in group 3 patients (36\%) than group 1 (4\%). Mucosal eosinophilia was rare. Biopsy specimens were taken in 25 patients from apparently normal mucosa $(2.5 \mathrm{~cm})$ from the edge of duodenal ulcers. Active duodenitis was found in sections from five patients and gastric metaplasia in $11(44 \%)$. Specimens from three apparently. quiescent ulcer scars also showed active duodenitis.

TABLE II-Incidence of Histological Features in Duodenal Bulbs अudged Endoscopically Normal and Abnormal

\begin{tabular}{|c|c|c|c|c|c|c|}
\hline \multirow{2}{*}{\multicolumn{3}{|c|}{ Histology }} & \multicolumn{4}{|c|}{ Endoscopic Appearance of Bulb } \\
\hline & & & \multicolumn{2}{|c|}{$\begin{array}{l}\text { Normal } \\
\text { (Group 1) }\end{array}$} & \multicolumn{2}{|c|}{$\begin{array}{c}\text { Abnormal (No Ulcer) } \\
\text { (Group 3) }\end{array}$} \\
\hline $\begin{array}{l}\text { Active duodenitis } \\
\text { Chronic inflammation } \\
\text { Gastric metaplasia } \\
\text { Eosinophilia } \\
\text { None of the above } \\
\end{array}$ & $\begin{array}{l}\cdots \\
\therefore \\
\cdots\end{array}$ & $\begin{array}{l}\cdots \\
\because \\
\cdots \\
\cdots\end{array}$ & $\begin{array}{r}0 \\
7 \\
1 \\
1 \\
20 \\
\end{array}$ & $\begin{array}{r}(25 \%) \\
(4 \%) \\
(4 \%) \\
(71 \%) \\
\end{array}$ & $\begin{array}{r}22 \\
29 \\
18 \\
3 \\
10 \\
\end{array}$ & $\begin{array}{l}(44 \%) \\
(57 \%) \\
(35 \%) \\
(6 \%) \\
(20 \%) \\
\end{array}$ \\
\hline Total & & & 28 & $(100 \%)$ & 51 & $(100 \%)$ \\
\hline
\end{tabular}

Correlation with Radiology.-Radiographs were available for 62 patients who underwent barium-meal examinations within one month of endoscopy (table III). None of the 19 endoscopically-proved duodenal ulcers were detected on $x$-ray examination, though deformity or enlarged folds were seen in all but three. Of 10 patients with active duodenitis three showed radiologically abnormal duodenal folds, but similar enlarged folds were seen on $x$-ray films in patients with ulcers and in others with no endoscopic abnormality.

TABLE III-Comparison of Endoscopic and Radiographical Appearances in Duodenal Bulb

\begin{tabular}{|c|c|c|c|c|c|c|}
\hline \multirow{2}{*}{ Group } & \multirow{2}{*}{$\begin{array}{l}\text { Endoscopic } \\
\text { Appearances }\end{array}$} & \multicolumn{4}{|c|}{ Radiographical Appearances } & \multirow{2}{*}{ Total } \\
\hline & & Normal & $\begin{array}{c}\text { Abnormal } \\
\text { Folds }\end{array}$ & Deformity & Ulcer & \\
\hline \multirow[t]{2}{*}{$\begin{array}{l}1 \\
2 \\
3 \\
3 a\end{array}$} & $\begin{array}{ll}\text { Normal . } & \ldots \\
\text { Ulcer } & . \\
\text { Visually abnormai } \\
\begin{array}{l}\text { Histological } \\
\text { duodenitis }\end{array}\end{array}$ & $\begin{array}{r}16 \\
3 \\
17 \\
6\end{array}$ & $\begin{array}{l}4 \\
7 \\
5 \\
3\end{array}$ & $\begin{array}{l}0 \\
9 \\
1 \\
1\end{array}$ & $\begin{array}{l}\mathbf{0} \\
\mathbf{0} \\
\mathbf{0}\end{array}$ & $\begin{array}{l}20 \\
19 \\
23 \\
10\end{array}$ \\
\hline & & & & & & \\
\hline
\end{tabular}

Clinical Features and Progress.-The ages and sex incidence of 22 patients with histologically active duodenitis (group 3a) are shown in table I. Five patients initially presented with acute bleeding; the remainder had typical ulcer-type dyspepsia of mean duration of seven years (range six months to 30 years). Three were particularly heavy beer drinkers. One Jamaican patient harboured strongyloides ova in the stool; however, symptoms and histological abnormalities persisted after their successful eradication. There was no evidence of biliary tract disease in any patient, but one was subsequently shown to have chronic pancreatitis. The remaining 21 patients were treated symptomatically as for duodenal ulcer and have been observed over 6-24 months. Two were lost to follow-up. Symptoms settled completely in three, continued mildly in five, and severely in 11. Eight of the latter have undergone repeat endoscopy. Two were found to have developed duodenal ulcers (at four and six months); in the remainder, visual and histological changes persisted. Two of these patients have recently undergone vagotomy and pyloroplasty (confirming the presence of active duodenitis on biopsy, and the absence of ulcer or other disease). Unfortunately, both patients remained symptomatic six months after operation. At endoscopy one had developed a small ulcer at the site of the pyloroplasty, despite an adequate vagotomy (as judged by an insulin test) and a fall of peak acid output after pentagastrin from a preoperative level of 36.9 to $15.9 \mathrm{mEq} / \mathrm{hr}$. The duodenal bulb mucosa looked normal, and three biopsies showed no evidence of active duodenitis. The other patient had an early positive insulin test, but a fall in peak acid output from 40.3 to $15.3 \mathrm{mEq} / \mathrm{hr}$. At endoscopy the duodenal bulb mucosa appeared normal, but one biopsy (out of three) showed a small area of active duodenitis.

\section{Discussion}

This study lacks a strict control group, since we have not examined asymptomatic individuals. As "controls" we have had to make use of 28 patients with normal appearances on endoscopy, whose symptoms were reasonably attributed to disease elsewhere. Experience of over 2,000 duodenoscopies has provided some impression of the range of normal visual appearances in the bulb. The abnormalities described in this study consist essentially of localized areas of mucosal congestion, oedema, and irregularity without overlying exudate or ulceration. Similar mucosal changes have been described at endoscopy (Belber, 1971) and at operation (MacCarty, 1924; Judd and Nagel, 1927; Kirklin 1929; Wellbrock, 1930; Rivers, 1931; Rhodes et al., 1968).

The limits of histological normality in duodenal bulb biopsies are difficult to define. The lamina propria includes chronic inflammatory cells in health (Doniach and Shiner, 1957) and these vary greatly in number from villus to villus and area to area (Aronson and Norfleet, 1962). Assessment of excessive round cell infiltration is therefore highly subjective, though some authors (Aronsen and Norfleet, 1962; Beck et al., 1965; Cheli, 1968; Rhodes et al., 1968; Suzuki et al., 1972) have used it as the main if not the only criterion for duodenitis. In our study chronic inflammation was seen in one or more biopsy in $57 \%$ of patients with visually abnormal bulbs, but also in $25 \%$ of patients with bulbs judged visually normal (table II).

Neutrophil infiltration through epithelia and cell atypia are easier to assess, and together have been used to define "active duodenitis." This was found in $44 \%$ of visually abnormal bulbs, and in none of the "control" group. Other authors have noticed neutrophil infiltration in the absence of ulceration (MacCarty, 1924; Judd and Nagel, 1927; Rivers, 1931) as well as activity of the glandular epithelium (Wellbrock, 1930). Gastric metaplasia in the bulb has been reported in $50-90 \%$ of patients with duodenal ulceration (James, 1964; Johansen, 1972; Suzuki et al., 1972) and has been related to hyperacidity both clinically and experimentally (Rhodes, 1964).

Gastric metaplasia was found in $41 \%$ of our patients with active duodenitis and in $44 \%$ of those with ulcer, but in only one out of 29 normal-looking duodenal bulbs. 
Studies of duodenitis based on radiology (Beck et al., 1965; Rhodes et al., 1968) have been criticized on the grounds that $x$-ray pictures cannot adequately exclude coexistent ulceration. Surgical follow-up studies show that barium meals detect a niche in only $38-75 \%$ of patients with active duodenal ulcers (Cooley, 1961), while endoscopic series suggest that $20-55 \%$ of such ulcers escape radiological detection (Dvorsky, 1969; Belber, 1971 ; Demling et al., 1971; Kasugi et al., 1971; Classen, 1972). In this series no ulcers were detected on review of radiographs from 19 patients with endoscopically proved ulceration (table III). It is unlikely that endoscopy missed ulcers in group 3 patients; two instruments were used when necessary, and patients with any deformity of pyloric canal or bulb were excluded.

The radiological finding of enlarged or abnormal duodenal folds ("cobble stone cap") has been said to have "low sensitivity but high specificity" for duodenitis (Schulman, 1970). Of our 22 patients with histological duodenitis 10 had had recent barium meals (table III). On careful review three studies showed enlarged duodenal folds. However, seven patients with a radiological diagnosis of enlarged folds were found endoscopically to have ulcers, and in four others endoscopy and biopsy appearances were normal.

This study has defined a group of 21 patients with unequivocal visual and histological abnormalities of the duodenal bulb, and unexplained dyspeptic symptoms. Many of the patients also showed gastritis on biopsy, and the clinical significance of these mucosal changes remains unproved. The concept that duodenitis is an early stage or variant of ulcer disease is attractive. The average ages and sex incidence of the two groups in this study were similar (table I) and they shared a high incidence of gastric metaplasia in the bulb. Since we do not perform follow-up endoscopy in patients with duodenal ulcers we do not know if duodenitis, as defined, can result from the healing of ulceration in the absence of scarring. However, two of our patients with active duodenitis developed ulcers in the short follow-up period. The mean duration of symptoms of patients with duodenitis (seven years, range two months to 30 years) was similar to that of ulcer patients (six years, range one month to 20 years). This study and others (Aronson and Norfleet, 1962; Cheli, 1968; Classen et al., 1970) show that in patients with duodenal ulceration histological duodenitis is usually confined to the ulcer area. Duodenal ulcer and active duodenitis are focal conditions.

We have shown that macroscopic abnormalities occur in the duodenal bulb in symptomatic patients in the absence of ulceration, and that these abnormalities usually reflect underlying histological inflammatory changes. It seems likely that these have some clinical significance, a hypothesis which can be examined only by long-term studies using repeated endoscopy and biopsy alongside other pathophysiological parameters. This study has also shown that the duodenal mucosa may be histologically normal when the endoscopic appearance is abnormal. The clinical relevance of this finding remains obscure, if adjacent inflammatory disease of the biliary system and pancreas can be excluded. Previous controversies in the field of gastritis emphasize the dangers of premature conclusions and the advantages of strict definition. Duodenitis is a histological term, and the presence of duodenitis in the absence of ulcer can be made only at surgery or by competent endoscopy and biopsy.

\section{References}

Aronson, A. R., and Norfleet, R. G. (1962). American fournal of Digestive Disease, 7, 506.

Baudin, J. B. (1837). Quoted by Ostrow and Resnick (1959).

Beck, I. T., et al. (1965). Gut, 6, 376 .

Belber, J. P. (1971). Gastroenterology, 61, 55.

Cheli, R. (1968). Digestion, 1, 175.

Classen, M., Koch, H., and Demling, L. (1970). Bibliotheca Gastroenterologica, $\mathbf{9}, 48$.

Classen, M. (1972). Archives Françaises des Maladies de l'Appareil Digestif, 61, 321 .

Cooley, R. N. (1961). American fournal of Medical Science, 2, 628.

Cotton, P. B. (1973). British Medical fournal, 2, 161.

Cotton, P. B., and Williams, C. B. (1972). British fournal of Hospital Medicine, 8,35 .

Demling, L., Classen, M., and Koch, M. (1971). International Symposium

(Prague), p. 261. Basel, Karger.
Doniach, I., and Shiner, M. (1957). Gastroenterology, 33, 71.

Dvorsky, A. (1969). Endoscopy, 1, 54.

James, A. H. (1964). Gut, 5, 285 .

Johansen, A. (1972). 2nd European Congress of Digestive Endoscopy, Paris, 1972 .

Judd, E. S., and Nagel, G. W. (1927). Surgery, Gynecology and Obstetrics,

45, 17. Gastrointestinal Endoscopy, 18, 9.

Kirklin, B. R. (1929). Radiology, 12, 377.

MacCarty, W. C. (1924). Journal of the American Medical Association, 83,

Ostrow, J. D., and Resnick, R. H. (1959). Annals of Internal Medicine, $51,1303$.

Rhodes, J., Evans, K. T., Lawrie, J. H., and Forrest, A. P. M. (1968). Quarterly fournal of Medicine, 145,151 .

Rivers, A. B. (1931). Annals of Internal Medicine, 4, 1265.

Rivers, A. B. (1931). Annals of Internal Medicine, 4, 1265.
Schulman, A. (1970). British fournal of Radiology, 43, 787 .

Suzuki, H., Kosu, T., Oi, I., Maruyama, M., and Takemoto, T. (1972) 2nd European Congress of Digestive Endoscopy, Paris, 1972. Wellbrock, W. L. A. (1930). Annals of Surgery, 91, 533. 